University of Rhode Island

DigitalCommons@URI

Open Access Master's Theses

1996

\title{
The Influence of Cooperative Learning on Problem Solving and Self-Esteem in Fourth Grade Elementary School Children
}

Neva Michelle Daniels

University of Rhode Island

Follow this and additional works at: https://digitalcommons.uri.edu/theses

\section{Recommended Citation}

Daniels, Neva Michelle, "The Influence of Cooperative Learning on Problem Solving and Self-Esteem in Fourth Grade Elementary School Children" (1996). Open Access Master's Theses. Paper 1685. https://digitalcommons.uri.edu/theses/1685

This Thesis is brought to you for free and open access by DigitalCommons@URI. It has been accepted for inclusion in Open Access Master's Theses by an authorized administrator of DigitalCommons@URI. For more information, please contact digitalcommons@etal.uri.edu. 
P 8

1036

1916

THE INFLUENCE OF COOPERATIVE LEARNING ON PROBLEM SOLVING AND SELF-ESTEEM IN FOURTH GRADE ELEMENTARY SCHOOL CHILDREN BY NEVA MICHELLE DANIELS

A THESIS SUBMITTED IN PARTIAL FULFILLMENT OF THE REQUIREMENTS FOR THE DEGREE OF MASTER OF SCIENCE IN HUMAN DEVELOPMENT AND FAMILY STUDIES

UNIVERSITY OF RHODE ISLAND 1996 36015375 


\begin{abstract}
Cooperative learning, problem solving and self-esteem were assessed in 48 fourth grade students from a public school in Rhode Island. The study provided data in order to answer three specific research questions: 1) Will the children who experience cooperative learning have higher self-esteem scores and higher math word problem scores than the children who did not receive cooperative learning?; 2) Is self-esteem associated with successful cooperative problem solving in the cooperative learning group? ; 3) Is actual behavior during cooperative learning associated with successful cooperative learning in the cooperative learning group? The findings suggest that cooperative learning was not associated with self-esteem. Further, no evidence was found to support the hypothesis that the cooperative group would achieve higher scores on the math tests than the group who did not experience cooperative learning. Interestingly, there was evidence that the cooperative learning group achieved higher scores on the daily math word problems than the group which did not receive cooperative learning. Applications of these findings are provided.
\end{abstract}




\section{Acknowledgments}

I would like to thank God, who has given me the opportunity to learn and grow. Thank you for blessing me in many wonderful ways, for always guiding me, and making my dreams come true !

I would like to thank my beautiful mother. Thanks for always believing in me and being there for me. I love you dearly !

I would like to thank my very patient and giving professors- Diane Horm-Wingerd and David Caruso. Thanks for all of the help, pep talks and guidance. You have helped me reach one of my life-long dreams.

I would like to thank the other members of my thesis committee. Thank you Gwenneth Rae, Barbara Culatta and David Byrd for your support and guidance.

Finally, I would like to thank my best friend and love of my life, Derek Cooper. Thanks for your love, friendship, prayers and encouragement. You truly are the sunshine of my life ! 


\section{Preface}

This manuscript was prepared under the guidelines of the American Psychological Association (APA) (1994).

The influence of cooperative learning on problem solving and self-esteem in fourth grade elementary school children was researched out of my personal interest in cooperative learning with children. After successfully using cooperative learning in my classroom, as a method of teaching young children, my own interest in the scientific research in this area was sparked. After learning that there had been limited research done in cooperative learning, problem solving, and self-esteem in children, I decided to research these areas. I am very interested in contributing to the research literature in the areas of cooperative learning, problem solving, and self-esteem. 


\section{Table of Contents}

Introduction.

1

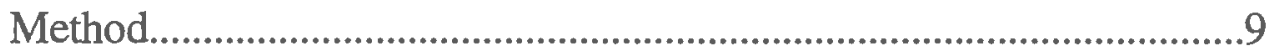

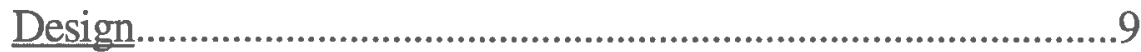

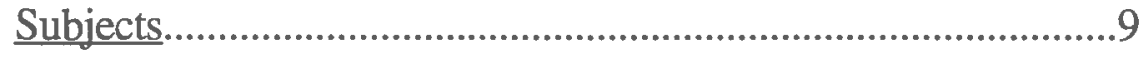

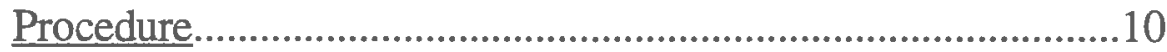

Measures.......................................................................................13

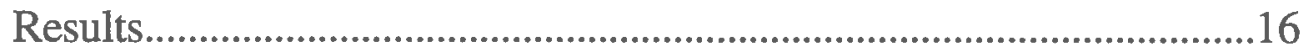

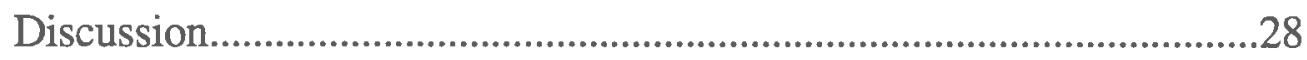

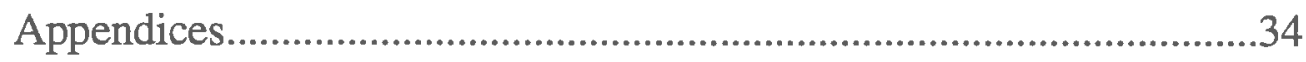

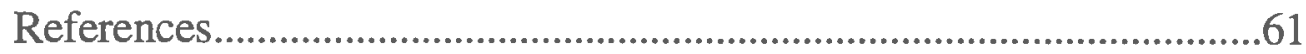




\section{List of Tables}

Table 1

Means of pre-and post tests for the cooperative learning

group and comparison groups 18

Table 2

Means, standard deviations, and significance levels of

the daily word problems for the cooperative learning

and comparison groups..

19

Table 3

Correlation of Piers-Harris pre- and post-tests and the

math pre-and post -tests...

Table 4

Correlation of Piers-Harris pre-and post-tests and the

cooperative group's daily word problem scores.

Table 5

Behavior code frequency table for the cooperative learning

group. .25

Table 6

Correlation of the cooperative group's daily word problem scores and their observed behavior. .26 


\section{List of Figures}

\section{Figure 1}

Graph of behavior code frequency for the cooperative

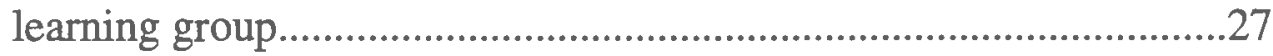




\section{Introduction}

Cooperative learning has been widely discussed as an instructional technique. However, there is limited research on cooperative learning. Only a few researchers have studied cooperative learning. Research in this area has been primarily done by Slavin (1980) and Sharan (1980).

Given the relatively limited amount of research on cooperative learning, there is little surprise that no studies have examined the relationship among cooperative learning, problem solving and selfesteem. According to Damon (1984), most of the scope of research in the area of cooperative learning has been in the areas of self-esteem and in the general area of learning, with no attention focused specifically on problem solving. The purpose of this thesis is to investigate the relationship of cooperative learning, problem solving, and self-esteem.

Over the past three decades, psychological and educational research has established a strong case that children can have a powerful influence on one another's intellectual, educational, and social emotional development. In 1984, Damon stated that many areas of research have even suggested that children can grasp educational materials easier through cooperative learning than through the traditional teacher directed instruction. According to Damon (1984), limited research has focused on cooperative learning 
in small groups and its relationship between student interaction, self-esteem and learning.

In 1984, Damon stated that the recent interest in cooperative learning has sprung from a number of convergent trends in education and psychology. These trends have come about through several theoretical bases on cooperative learning in education.

According to the Piagetian view, when children disagree with one another, they encounter both social and cognitive conflict. This important experience helps children to form important realizations. First, children become aware that there are points of view other than their own. Second, they learn to examine their own point of view and to reassess its validity. Third, they learn that they must justify their own point of view and communicate it thoroughly to others if others are to accept it as valid. This helps children to work out their understanding of the issue at hand so that they are able to express their views clearly and convincingly (Damon, 1984).

In Piaget's view, children gain both social and cognitive benefits from peer interaction. Tudge and Caruso (1988) have reported that Piaget believed that opportunities for becoming less egocentric are much more common when children discuss things with one another because then they must face the fact that everyone may not have the same perspective on any given situation. This exchange of perspectives allows children to learn how to take different points of view into account. Piaget believed that the cognitive benefits are the feedback in the give and take of peer interaction. According to Damon (1984), Piaget also believed that these social and cognitive 
benefits were directly related, in that improved social communication instigates progressive cognitive change. When people communicate well with one another, they realize the need to explain and justify their beliefs, which in turn forces them to understand their beliefs as much as possible. Therefore, a sense of social responsibility in reasoning will lead to improvements in the logical quality of one's ideas.

In Piagetian theory, peer interaction works mostly as a mechanism for change. Piaget believed that the disturbing feedback that was provided by peer interaction initiates a process of intellectual reconstruction in the child. But once this process has begun, according to Piaget's theory, the main work of formulating new knowledge is done by the individual, as a means of solitary reflection, by symbolically manipulating the world and making inferences on the basis of these symbolic manipulations (Damon, 1984).

In the view of Vygotsky, peers benefit from one another by internalizing the cognitive processes implicit in their interactions and communications. A peer encounter can present its participants with strategies that are specifically appropriate for solving cognitive tasks. In the math and science area, peer communication can help children master deductive and combinatorial reasoning (Forman, 1983).These skills follow from peer communications in which new solutions are generated collaboratively by peers and then are mutually discussed, tried out, and corrected. 
The third view by Sullivan considers the "coconstruction" of ideas that occurs during peer exchange. Peers approach one another as equals and work out concepts through the cogeneration and consensual validation of intellectual strategies. They learn from one another not by copying or adopting the other's competence, but by mutually devising plans together in a collaborative effort. In Sullivan's view, collaboration has several educational advantages. It encourages participants to engage in "discovery" learning, a strongly motivated learning process especially appropriate for the grasping of many basic concepts. It also enables children to explore new possibilities together, in a manner which has no limitations (Damon, 1984).

Although relatively little research has been completed with cooperative learning, a larger body of literature is available in the areas of problem solving and self-esteem. Many researchers have studied problem solving such as Polya (1973), Lester and Garofalo (1982), and Silver (1983). Problem solving is another aspect of this research study. According to Hudgins (1960), groups furnish more correct solutions to problems than subjects that work on the same problems as individuals.

A problem solving approach concentrates on solving and reasoning out problems. It may entail learning about and practicing Polya's (1973) four phase method for solving problems:

1. Understand the problem(e.g. define the unknown and decide what information is relevant);

2. Devise a plan (generate possible solution strategies and 
choose the most appropriate one);

3. Carry out the plan;

4. Check the results.

Children can also learn and practice heuristics: problem solving aids such as drawing a picture, organizing data into a list or table, considering a simpler version of a problem, or determining whether a problem is similar to familiar problems (Polya, 1973).

Even more research has investigated children's self-esteem. Researchers in this field include Adler (1927), Sullivan (1953), Horney (1966), Coopersmith (1967), Glasser (1975), Piers (1977) and Bean (1992). Self-esteem is defined as the way one feels about oneself, including the degree to which one possesses self-respect and self-acceptance. Self-esteem is the sense of personal worth and competence that persons associate with their self concepts (Corsini, 1984).

Maslow (1970) created a hierarchy of needs. According to those needs, all people have a need to have a stable regard or self concept. There are two sets of esteem needs. In the first set there is a desire for strength, achievement, adequacy, mastery, competence, selfconfidence and a degree of freedom. The second set of esteem needs involves the desire for prestige, status, recognition, attention, dignity, and appreciation. All of the second set are characteristics of esteem based on others' views of the person (Corsini, 1984).

Horney (1966) investigated self-esteem and reported that love, warmth, and acceptance are important in achieving self-esteem. 
Coopersmith (1967) found that high self-esteem results from parental acceptance, setting of limits, and freedom for individual action within realistic limits. Glasser (1975) saw self-esteem as a multidimensional concept because it exists in degrees. He also viewed self esteem as being related to one's personal identity.

L'Ecuyer (as cited in Mussen, 1983) created a multidimensional model of self-esteem composed of five structures:

1. The material self

2. The personal self

3. The adaptive self

4. The social self

5. The self-non-self

Within each structure, there are sub-categories. The material self is composed of the somatic self and the possessive self; the personal self is subdivided into self-image and self-identity; the adaptive self is comprised of self-esteem and self-activity; the social self refers to preoccupations and social activities; and the self-nonself includes references to others and others' opinion of self. Self esteem, in this model is a substructure under the adaptive self, and is further divided into feelings of competence and personal worth (L'Ecuyer as cited in Mussen, 1983).

Bean (1992) found that self-esteem had four conditions:

1. Sense of Uniqueness

2. Sense of Connectiveness

3. Sense of Power

4. Sense of Models 
The sense of uniqueness is an important condition of selfesteem in which children acknowledge and respect the qualities and characteristics about themselves that are special and different, and they must receive confirmation from other people that those qualities and characteristics are important and good.

The sense of connectiveness refers to the ability for children to gain satisfaction from the people, places and things that they feel connected to, and the value of those connections must be acknowledged by the people who are important to them.

The sense of power is important to children's self-esteem because children need to have the competence to do what they must do, the resources required to effectively express their competence, and the opportunity to use their competence to influence important circumstances in their lives.

The sense of models is a condition of self-esteem because children must be able to refer to human, philosophical and operational models to help them make sense of the world. They use these reference points to help them set their own goals, values, personal standards and ideals (Bean,1992).

Sears and Sherman (1966) found that self-esteem results when children are able to predict success for important facets of experience. When children are able to think positively about their own success, their self-esteem is enhanced.

In light of the research in the areas of cooperative learning, problem solving, and self-esteem, it appears that children would benefit greatly from cooperative learning. Through this research 
study, the benefits of cooperative learning, problem solving, and selfesteem are assessed.

There are three hypotheses for this research study. One hypothesis that this research seeks to test is that elementary children who experience cooperative learning (cooperative learning group), will have higher self-esteem scores and higher math word problem scores than the children who did not experience cooperative learning (comparison group).

The second hypothesis is a within group question in the cooperative learning group in which the students with high selfesteem are predicted to also have high test scores on the math word problems test.

The third hypothesis is a within group question in the cooperative learning group in which the behavior during the cooperative learning activity is predicted to be associated with successful cooperative learning.

Research in this area was justified due to the researcher's work experiences with fourth grade students using cooperative learning with math problems. This area was also selected due to its limited research, in an effort to contribute more research in this area of education. 


\section{Method}

\section{Subjects}

The subjects were 48 fourth grade students, 24 for the cooperative learning group and 24 for the comparison group, selected from three public elementary school classrooms in Rhode Island. Two classrooms, one for the cooperative learning group and one for the comparison group, were randomly selected from the three fourth grade classrooms in the school. Students from the remaining classroom were randomly assigned to the cooperative learning group or comparison groups as needed to reach 24 students in each group. This school was chosen because its students represented an ethnically and racially diverse population. This was a control designed to eliminate racial and ethnic bias in research.

\section{$\underline{\text { Design }}$}

The design for this investigation was a quasi-experimental pretest post-test control group design. A self-concept measure and mathematics word problems were administered at the beginning and the end of the study in a pre-test, post-test fashion for all subjects. 


\section{Procedure}

All subjects were given the informed consent form to take home for the parents/guardians to complete one week prior to the pretesting time. All subjects were also asked to give assent on a child assent form. All consent forms were distributed and collected by the teachers of the two classes. On the day of the pretesting, the researcher collected all of the informed consent and assent forms. The parental consent form is shown in Appendix A. The child assent form is shown in Appendix B. All subjects (within the cooperative learning and comparison groups) were given a number for the purpose of confidentiality.

The cooperative learning group was placed in same sex pairs, while the comparison group was not in pairs but were assessed as individuals. The cooperative learning subjects were divided by gender and same sex pairs were randomly assembled through the method of choosing names out of a box.

\section{Pre-tests}

The Piers-Harris Children's Self-Concept Scale was administered to each group in each classroom. Both the instructions and the items were read aloud to all of the subjects. The subjects answered yes or no to each item by circling their response for each item on the answer form. This process lasted approximately 20 minutes. Then, on the following day, a worksheet containing 20 
mathematical word problems was presented to each group to be completed individually. This process lasted approximately 45 minutes. These math word problem worksheets were collected and scored by the researcher.

\section{Cooperative Learning Group}

The members of the cooperative learning group received a lesson on problem solving. This lesson consisted of an explanation and example using Polya's (1973) 4-Step problem solving process. The steps of this problem solving process are: (1) read the problem; (2) devise a plan; (3) carry out the plan; (4) check the results.

The cooperative learning group was taken out of the classroom in randomly assembled same-sex pairs. Pairs were used in this research in reflection of previous research. According to Tudge (1992), collaborative processes, particularly those engendered by dyads, featuring different levels of competence have a shared understanding that may be created from what were originally two different understandings. In this research, each pair was taken to another room where they were given three math word problems to complete cooperatively in 10 minutes. This activity occurred five days a week for two weeks. Within this time, 30 math word problems were completed using cooperative learning for each pair in this group. See Appendix $G$ for the daily sequence of problems which were solved by each pair in this study.

The cooperative learning pairs were observed during their 10 days of solving 30 math problems. Each member of the pairs was 
observed to determine the use of suggestions, questions, unrelated comments, and representations. The behaviors of each child was recorded separately on a behavioral coding sheet. During each cooperative learning activity, the researcher observed the behavior of each cooperative learning pair and kept track of their behaviors by marking tallies under the appropriate column on the coding sheets. A sample of the coding sheet is included in appendix $\mathrm{H}$.

\section{Comparison Group}

The members of the comparison group received the same lesson on problem solving as the cooperative learning group. This lesson consisted of an explanation and example using Polya's (1973) 4-Step problem solving process. The steps of this problem solving process are: (1) read the problem; (2) devise a plan; (3) carry out the plan; (4) check the results.

The comparison group completed three word problems each day for two weeks. The members of the control group worked independently. The same 30 word problems were used in both the comparison and cooperative learning groups. The behavior of the comparison group was not observed as they individually solved the daily math problems.

\section{Post-tests}

On the third week, the two groups were given the Piers-Harris Children's Self Concept Scale again. The next day, the two groups individually completed a mathematical word problem test containing 
20 word problems. This post-test had the same word problems as the pre-test but the problems were arranged in a different order in the post-test. This increased the reliability of the pre- and post-tests. These tests were collected and scored by the experimenter.

\section{Measures}

The Piers-Harris Children's Self-Concept Scale was developed in 1969 and consists of 80 declarative sentences (e.g. I am a happy person). This scale was used with all subjects. This measure is age and grade appropriate for the fourth grade and has adequate validity and reliability for research purposes (Piers, 1977). The respondents are required to answer yes or no to each item (Piers, 1977). There are six item "clusters" that are analyzed in this self-concept test. These clusters represent self-evaluations of : 1) behavior;2) intellectual and school status; 3) physical appearance and attributes;
4) anxiety ;
5) popularity ; and
6) happiness and satisfaction (Keyser \& Sweetland, 1984). According to Keyser and Sweetland (1984), the internal consistency of the test as a whole is relatively high and alpha coefficients of .90-.91 have been reported for male and female populations using this test. According to Jeske (as cited in Mitchell, 1985), the test-retest reliability coefficients from numerous studies range from .42 and .96 , and the internal consistency estimates for the total score range from .88 to .93 . Estimates of content, criterion-related and construct validity from numerous empirical studies have generally been quite acceptable. 
See Appendix C for the Piers-Harris Self-Concept Scale, see Appendix D for the Piers-Harris Profile Form, see Appendix E for copyright information.

Grade appropriate mathematical word problems from the Fourth Grade Macmillan Mathematics Book (1987) and The Mathematics Experience-Grade 4 (Houghton Mifflin, 1992) were used to measure differences in problem solving skills. Problem solving skills were assessed using math word problems in two ways: (1) Math word problems pre-test and post-test and (2) practice math word problems. The word problems that were used for the pre-test and post-test were taken from The Mathematics Experience-Grade 4 (Houghton Mifflin, 1992). These problems entailed addition, subtraction, multiplication, division, fractions, time, distance, measurement and money. Several sample problems are shown in Appendix F. The math word problems used in the daily word problems practice were taken from The Fourth Grade Macmillan Mathematics Book (1987). These problems entailed addition, subtraction, multiplication, division, fractions, time, distance, measurement and money. Several sample problems are shown in Appendix G. Because these math tests are not published instruments, there is not any reliability or validity information available. However, due to the source, content validity is assumed.

A cooperative learning behavior coding system was used for the cooperative learning group in order to record relevant behaviors that occurred during the cooperative interaction sessions for each pair. The categories for this coding system included : Suggestions/ 
Statements, Questions, Unrelated Comments and

Representing/Drawing/Writing. The coding system was designed specifically for use in this study. Thus, no studies of reliability and validity are available for this coding system. 


\section{RESULTS}

It was predicted that the children who experienced cooperative learning would have higher self-esteem scores and higher math word problem scores than the children who did not experience cooperative learning. An analysis of covariance using the pre- Piers-Harris score as the covariate, was completed to investigate differences in self-concepts of children in the cooperative learning and comparison groups. No significant difference was found between the self-esteem post-test scores for the cooperative learning and the comparison groups, $\mathrm{F}(1,26)=0.037, \mathrm{p}=0.849$. Children in the cooperative learning group did not differ in self-esteem scores from the children in the comparison group. See Table 1 for means of the self-esteem and math pre- and post-test scores for the cooperative learning and comparison groups.

Group differences in solving math problems were investigated through analyzing two different measures. One was the math posttest and the other measure was scores obtained on daily word problems completed over 10 days. An analysis of covariance, using the math pre-test score as the covariate, was completed to determine if the cooperative learning and comparison groups differed on the post-test scores for the math word problem tests. There was no significant difference found between the two groups on the math post-test scores, $\mathrm{F}(1,30)=0.882, \mathrm{p}=0.355$. Thus, children in the cooperative learning group did not have significantly higher math word problem test scores than the children in the comparison 
group. Table 1 listsd the pre-and post-test math test scores for the cooperative learning and the comparison groups.

A MANOVA indicated that overall, across the 10 daily math problems, there was a significant difference between the two groups, $\mathrm{F}(10,13)=6.369, \mathrm{p}=.001$. Follow-up univariate ANOVAs indicated that out of the 10 problems, the cooperative learning group did significantly better than the comparison group on 8 problems, the comparison group did significantly better than the cooperative learning group on 1 problem, with no difference evident on 1 problem. Please refer to Table 2 for a listing of the means, standard deviations, $F$ values, degrees of freedom, and probability values associated with these follow-up univariate tests.

As can be seen on Table 2, there is a pattern in which the cooperative learning group had significantly higher mean scores than the comparison group on 8 consecutive days out of the 10 (days 2 through 9). The comparison group had the same mean score on day 10 as the cooperative learning group and the comparison group had a significantly higher mean score on day 1 . 


\section{TABLE 1}

Means of pre-and post-tests for the cooperative learning

and comparison groups

$\underline{\text { Self-Esteem }}$

Math Problems

$\underline{\text { Pre-test }} \underline{\text { Post-test }} \quad \underline{\text { Pre-test }}$ Post-test

Cooperative

learning

group

means

Comparison

group

means
66.1

$\mathrm{n}=20$

69.0

$\mathrm{n}=17$

17.8

26.7

$\mathrm{n}=20$

$\mathrm{n}=19$

69.9

72.8

19.1

23.7

$\mathrm{n}=17$

$\mathrm{n}=12$

$\mathrm{n}=17$

$\mathrm{n}=14$ 


\section{TABLE 2}

Means, standard deviations, and significance levels of the daily word problems for the cooperative learning and comparison groups

\section{DAILY}

WORD

\section{$\frac{\text { PROBLEMS }}{\text { Cooperative }} \frac{\text { GROUPS }}{\text { learning Comparison }}$}

\begin{tabular}{|c|c|c|c|c|c|}
\hline 1 & $\begin{array}{l}19.80 \\
(27.09)\end{array}$ & $<$ & $\begin{array}{l}33.00 \\
(31.88)\end{array}$ & $7.354(1,22)$ & $\mathrm{p}=.013$ \\
\hline 2 & $\begin{array}{l}83.00 \\
(17.44)\end{array}$ & $>$ & $\begin{array}{c}68.64 \\
(27.70)\end{array}$ & $30.842(1,22)$ & $\mathrm{p}=.0001$ \\
\hline 3 & $\begin{array}{l}64.85 \\
(38.30)\end{array}$ & $>$ & $\begin{array}{c}40.85 \\
(41.12)\end{array}$ & $35.049(1,22)$ & $\mathrm{p}=.0001$ \\
\hline 4 & $\begin{array}{l}49.50 \\
(16.93)\end{array}$ & $>$ & $\begin{array}{r}30.00 \\
(9.95)\end{array}$ & $32.731(1,22)$ & $\mathrm{p}=.0001$ \\
\hline 5 & $\begin{array}{l}84.85 \\
(27.65)\end{array}$ & $>$ & $\begin{array}{l}53.07 \\
(39.39)\end{array}$ & $24.465(1,22)$ & $\mathrm{p}=.0001$ \\
\hline 6 & $\begin{array}{l}86.00 \\
(22.54)\end{array}$ & $>$ & $\begin{array}{l}54.00 \\
(33.99)\end{array}$ & $44.530(1,22)$ & $\mathrm{p}=.0001$ \\
\hline 7 & $\begin{array}{l}42.75 \\
(28.47)\end{array}$ & $>$ & $\begin{array}{l}20.39 \\
(28.93)\end{array}$ & $18.004(1,22)$ & $\mathrm{p}=.0001$ \\
\hline 8 & $\begin{array}{l}74.55 \\
(26.26)\end{array}$ & $>$ & $\begin{array}{l}39.60 \\
(37.47)\end{array}$ & $40.780(1,22)$ & $\mathrm{p}=.0001$ \\
\hline 9 & $\begin{array}{l}39.80 \\
(33.55)\end{array}$ & $>$ & $\begin{array}{l}18.09 \\
(31.09)\end{array}$ & $23.749(1,22)$ & $\mathrm{p}=.0001$ \\
\hline 10 & $\begin{array}{l}10.00 \\
(30.78)\end{array}$ & $=$ & $\begin{array}{l}10.00 \\
(31.62)\end{array}$ & $2.095 \quad(1,22)$ & $\mathrm{p}=.162$ \\
\hline
\end{tabular}

Note: Numbers in the table are group means; standard deviations are enclosed in parentheses. ${ }^{*}=$ significant difference at the .01 level. 
The second hypothesis predicted that a high test score on the Piers-Harris self-esteem measure would be associated with successful cooperative problem-solving, as measured by the math test, for the subjects in the cooperative learning group. The Pearson Product Moment correlation was used to investigate the relationship between self-esteem and math word problem scores. Correlations were computed for the pre- and post Piers-Harris and the pre-and post math tests for the cooperative learning group. Please refer to Table 3 for the correlation matrix.

As can be seen on Table 3, there was a moderate correlation between self-esteem (Piers-Harris post-test) and mathematics test performance (mathematics post-test) $(r=0.46)$. There was a low positive correlation between the math post-test and the Piers-Harris self-esteem pre-test $(r=.29)$. Taken together, these correlations do not support the hypothesis of a strong relationship between selfesteem and performance on the math test for subjects in the cooperative learning group.

As listed on Table 3, there was a strong direct correlation between the pre- and post- Piers-Harris tests $(r=.92)$. A moderate correlation was found between the pre- and post- math problem tests $(\mathrm{r}=.63)$. These findings suggest that self-esteem tended to remain stable (means $=$ pre-test: 66.1 , post-test: 69.0 ) while the math scores changed over the course of the study (means= pre-test: 17.8, post-test: 26.7 ). 
A Pearson Correlation was done to analyze the relationship between the cooperative learning group's daily word problem scores and their self-esteem. A variable was created called "coop" which is the sum of the cooperative learning group's daily word problem scores. Please refer to Table 4 for a summary of the data.

As shown on Table 4, there was a low negative correlation between the cooperative learning group's daily word problem scores and their scores on self-esteem measures on the pre-test $(r=-.197)$ and post-test $(r=-0.187)$. Thus, no relationship between self-esteem and cooperative problem-solving was found for the cooperative learning group in this study.

The frequency of statements, questions, and representations of the cooperative learning group for each of the daily math word problems was assessed to investigate the relationship of these behaviors to successful cooperative learning. The created variables were cooperation (sum of cooperative group scores over the 10 days of math problems), statement (sum of statements), question (sum of questions), and representation (sum of representations).

As can be seen on Table 5 and figure 1, there were more suggestions made than any of the other behaviors for 7 of the 10 days. There were more representations (drawing, writing, representations the problem on paper) than suggestions on the first 3 days. There were more representations than questions and unrelated comments for each of the 10 days. There were more questions than unrelated comments for 9 out of the 10 days. 
A Pearson Correlation was done to analyze the relationship between the cooperative learning group's daily word problem (problem-solving) scores and their behavior during the cooperative activity. Please refer to Table 6 for a summary of the data.

As can be seen on Table 6, there was little, if any, relationship between the cooperative learning group's daily word problem scores and the statements, questions and representations they produced in this study. The relationship between the cooperative learning group's score and statements made during the study was a zero correlation $(\mathrm{r}=-.053)$. The relationship between the cooperative learning group's score and questions asked during the study was a low positive correlation ( $\mathrm{r}=.192)$. The relationship between the cooperative learning group's score and representations (writing, drawing) made during the study was a zero correlation ( $r=-.097)$. Thus, there was no relationship between behavior during the cooperative learning activity and daily word problem scores in the cooperative learning group. 


\section{TABLE 3}

Correlation of Piers-Harris pre-and post-tests and the math pre-and post-tests

PEARSON CORRELATION MATRIX

Piers-Harris

Pre-test Post-test
Math Test

Pre-test Post-test

Piers-Harris

$\begin{array}{ll}\text { Pre-test } & 1.000 \\ & \mathrm{n}=20 \\ & (0.001)\end{array}$

Post-test
0.919
1.000
$\mathrm{n}=17$
$\mathrm{n}=17$
$(0.001)$
(0.001)

Math Test
Pre-test
0.028
0.193
1.000
$n=20$
$\mathrm{n}=17$
$\mathrm{n}=20$
(0.91)
(0.46)
$(0.001)$
Post-test

$\begin{array}{ll}0.292 & 0.462 \\ \mathrm{n}=19 & \mathrm{n}=17 \\ (0.23) & (0.06)\end{array}$
0.628
1.000
$\mathrm{n}=19$
$\mathrm{n}=19$
(0.004)
(0.001)

Note: Probability values are enclosed in parentheses. 
TABLE 4

Correlation of Piers-Harris pre-and post-tests and the cooperative learning group's daily word problem scores PEARSON CORRELATION MATRIX

Piers-Harris

Pre-test Post-test
Cooperative group's

daily problems

$\underline{\text { score }}$

$\underline{\text { Piers-Harris }}$

$$
\begin{array}{ll}
\text { Pre-test } & \begin{array}{l}
1.000 \\
\mathrm{n}=20 \\
(0.001)
\end{array}
\end{array}
$$

Post-test

$$
\begin{array}{ll}
0.919 & 1.000 \\
\mathrm{n}=17 & \mathrm{n}=17 \\
(0.001) & (0.001)
\end{array}
$$

Cooperative

$-0.197 \quad-0.187$

1.000

group's daily

$$
\mathrm{n}=20
$$

$\mathrm{n}=17$

$\mathrm{n}=20$

problems score $(0.41)$

$(0.47)$

$(0.001)$

Note: Probability values are enclosed in parentheses. 


\section{TABLE 5}

Behavior Code Frequency for the Cooperative Learning Group

\section{Daily}

Totals Suggestions $\underline{\text { Questions }}$ Unrelated Representations

$\begin{array}{llccc}\text { Day } 1 & 49 & 17 & 9 & 128 \\ \text { Day } 2 & 95 & 12 & 2 & 100 \\ \text { Day } 3 & 50 & 9 & 1 & 75 \\ \text { Day } 4 & 270 & 37 & 17 & 93 \\ \text { Day } 5 & 122 & 8 & 10 & 62 \\ \text { Day } 6 & 236 & 39 & 16 & 106 \\ \text { Day } 7 & 185 & 28 & 6 & 109 \\ \text { Day } 8 & 163 & 24 & 2 & 91 \\ \text { Day } 9 & 145 & 15 & 6 & 80 \\ \text { Day } 10 & 168 & 19 & 4 & 81\end{array}$


TABLE 6

Correlation of the cooperative learning group's daily word problem $\underline{\text { scores and their observed behavior }}$ PEARSON CORRELATION MATRIX

Cooperative group's

daily word problem scores

Cooperative group's

1.000

daily word problem

$\mathrm{n}=20$

$\underline{\text { scores }}$

$(0.001)$

Statements

$-0.053$

$\mathrm{n}=19$

(0.83)

Questions

0.192

$\mathrm{n}=19$

(0.43)

Representations

$$
\begin{aligned}
& -0.097 \\
& n=19 \\
& (0.69)
\end{aligned}
$$

Note: Probability values are enclosed in parentheses. 


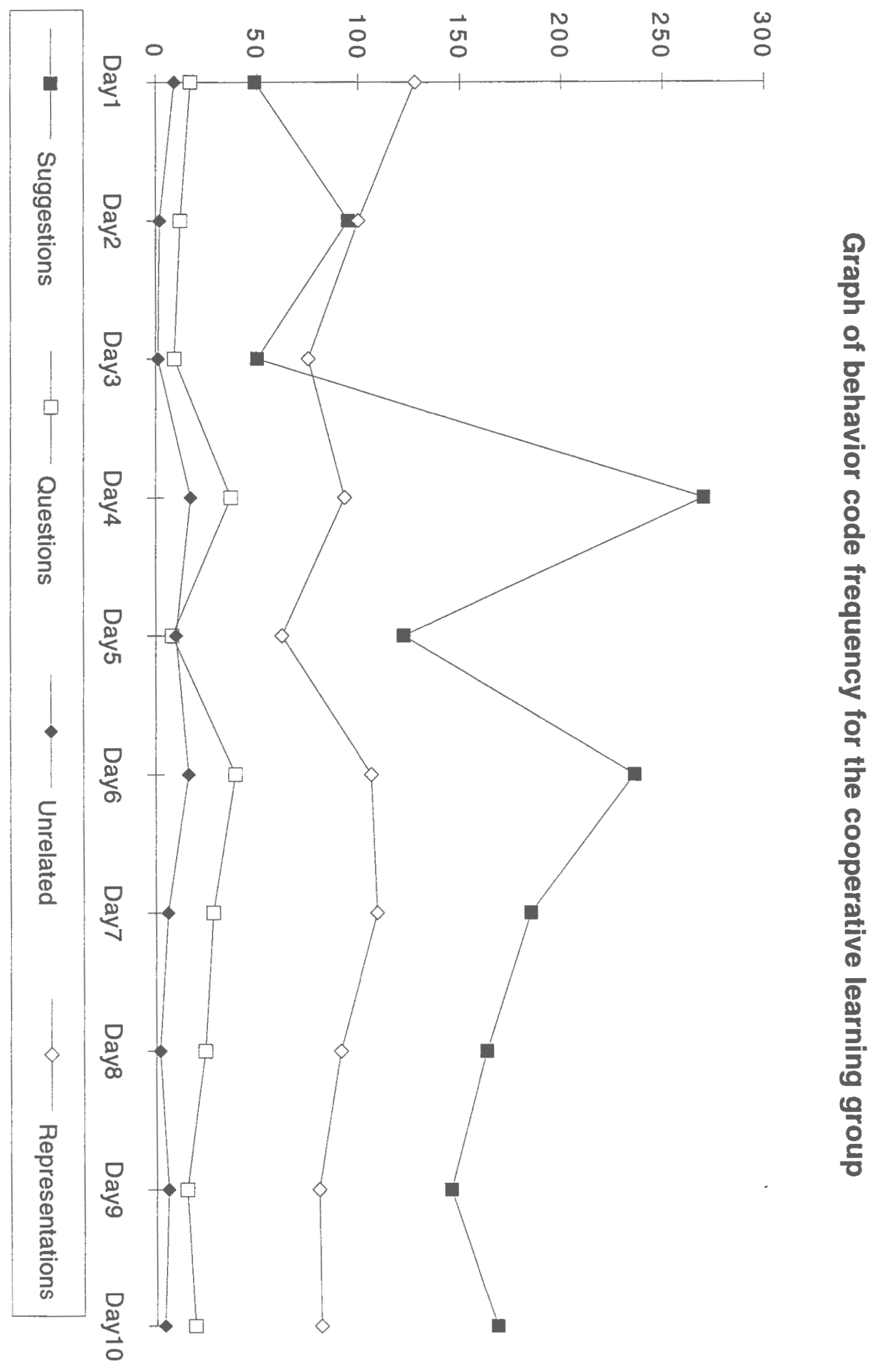




\section{DISCUSSION}

The results clearly do not support the hypothesis that elementary children who experienced cooperative learning (cooperative learning group) had higher self-esteem scores than the children who did not experience cooperative learning (comparison group).

One potential explanation for this lack of relationship between self-esteem and problem-solving is the short length of time of the study. Perhaps, self-esteem is a characteristic that changes over time. If so, this change may occur at an interval longer than 3 weeks. Perhaps a longer study may yield significant results. Also, a longer study may allow the cooperative group more time to work together and possibly the behaviors observed would play a significant role in this type of study. With a longer study, the cooperative learning group may have gained significant math test scores in the study.

Interestingly, there was an overall significant difference between the two groups on their performance of the daily math word problems (problem-solving). This data supports the hypothesis that the cooperative learning group would have higher math word problem (problem-solving) scores than the children who did not experience cooperative learning. It appears that children greatly benefited from their cooperative learning experience due to the increase in problem-solving scores as demonstrated by their performance on daily math problems. The cooperative learning math problem solving scores were much higher than the scores achieved in 
the comparison group. A possible reason for this outcome may be the high frequency of suggestions observed as the pairs cooperatively solved the daily math problems.

A reason for this pattern may be due to the procedures used to test math problem solving. Instead of the math pre- and post-test being administered to individuals, perhaps it would have been better to have the post-test completed by the cooperative learning group in pairs instead of as individuals. This method may yield different results and assess cooperative learning in a more accurate way.

However, the results from the math post-test does not support the hypothesis of the cooperative learning group having higher math scores (on tests) than the group of children who did not experience cooperative learning on the math post-test scores. There was no significant difference between the cooperative learning and comparison groups in the math post-test scores.

The results clearly do not support the second hypothesis. This hypothesis was a within group question in the cooperative learning group in which the students with high self-esteem would also have high test scores on the math word problems test.

The results also indicated that there was no significant relationship between self-esteem and successful cooperative problem-solving in the cooperative learning group. Results also have shown that there was no significant relationship between behavior during cooperative learning activity and successful cooperative learning. 
A reason for this pattern may be that the length of the study may have been too short and the cooperative learning group may have needed more time together in order for their group problemsolving skills to be enhanced. Also, the length of time for the daily word problems could have been unlimited instead of 10 minutes per group, in order for problem solving time to be assessed.

Other variables which could have impacted the results in this study are changing the nature of math questions, the use of manipulatives to maximize learning, more control on the comparison group, and videotaping the study to have more accuracy in assessing and reporting the behavioral data for both the cooperative learning and comparison groups.

In an effort to assess the process of problem solving in a more accurate way, maximizing the systems used in the study while minimizing the level of error in the study, the pre- and post-tests as well as the daily math problems should be limited to two or three mathematical functions. In this way, if children's addition, subtraction and multiplication are the only areas being assessed, then there can be more of an emphasis in these areas in the pre-tests to assess levels of expertise as well as to define problem-solving skills in these areas. As the study progresses, the children could practice problem solving through math problems in these areas and take post-tests in these areas. By minimizing the mathematical areas which are assessed, the level of error is also minimized due to the ease of assessing the performance level in only a few areas instead of many areas. 
The behavior of children could be more accurately assessed through the use of videotape. The researcher could tape the daily problem solving in both groups in order to assess the process of problem solving in depth.

Another limitation in the study was that there were slight environmental differences between the cooperative learning and comparison groups during the daily problem solving times. The comparison group could have been taken out of the classroom and observed by the researcher in order to add more research control, as well as adding a similar environment to the cooperative learning group. Greater steps could be taken to ensure unlimited time for this group as well as the cooperative learing group.

Another limitation in this study is that the behavior coding system was created for this project and no formal studies of reliability and validity have been conducted. Thus, accuracy of this measure is unknown.

In addition to the above issues, another limitation characterized this study. This limitation was the small number of subjects used in this study. A larger number of subjects could bring more results and may indicate trends in group behavior and problem-solving success in a more accurate way.

The findings of this study suggest that children seem to work significantly better together on daily word problems in which they would be able to practice their problem-solving skills together than children working on the same problems individually. According to the results of this study, it would be beneficial for children to work 
cooperatively in the classroom on a daily basis. The results show that cooperative learning leads to better achievement in solving daily math problems. Through cooperative learning, children would be able to learn valuable problem-solving skills, as well as being able to work as a part of a team.

A possible explanation for the results on day 1, with the comparison group having a significantly higher mean score than the cooperative learning group, could be that because this is the first day of the study, the cooperative learning group was not used to working in pairs and answered the questions as two individuals would have. Also, the individuals within the cooperative learning group may have felt uncomfortable answering the questions with their new found partner.

Teachers can encourage cooperative learning in the classroom in a number of subjects. These subjects include: Mathematics, Social Studies, English (whole-process writing), Science (lab activities) and Reading (cooperative reading groups). In these areas, children will be able to understand why they make the choices that they make because they will have to "prove" their answers. This process may increase children's understanding of information, as well as enhancing their problem-solving and communication skills.

The next steps in this research could include extensive research of self-esteem in children in cooperative groups. Self-esteem could be assessed over months and years with the same study or repeated studies. Perhaps a longitudinal study would assess this experimental question in greater depth. 
Another next step in research could include a study assessing the role of team work and leadership skills in cooperative learning. Perhaps a study assessing the role of team work and leadership using same gender cooperative learning groups verses mixed gender cooperative learning groups may assess this experimental question in a unique way and bring greater depth to the research in this area. 
Appendix A

Parental Consent Form 


\title{
Appendix A \\ Parent Consent Form
}

\author{
The University of Rhode Island \\ Department of Human Development and Family Studies \\ Transition Center \\ Lower College Road \\ Kingston, R.I. 02881
}

The Influence of Cooperative Learning

on Problem Solving and Self-Esteem

in Fourth Grade Elementary School Children

\section{PARENTAL/GUARDIAN CONSENT FORM FOR RESEARCH}

I have been asked to allow my child to participate in the research project described below. The purpose of this letter is to explain the project to me in detail. I should feel free to ask questions. If I have any questions, Neva Daniels, the person mainly responsible for this study, (401) 792-2758, will discuss them with me.

I have been asked to allow my child to participate in a study which will investigate the influence of cooperative learning on problem solving and self-esteem in fourth grade elementary school children.

If I decide to allow my child to participate in this study here is what will happen: My child will be asked to complete a self-concept measure and math word problems on two occasions. The self-concept measure is commonly used with elementary school children. The researcher will read statements such as "I am good at school" and the children will respond by circling "yes" or "no" on an answer sheet. My child will also complete math word problems from a fourth grade textbook. On both occasions, the self-concept measure and math word problems will be given to the classroom as a whole. After the first time the self-concept measure and the math word problems are given, children will be randomly divided into two groups. If my child is in group \#1, he/she will be paired with another student of the same gender and complete math word problems together. If my child is in group \#2, he/she will complete the same math word problems as group \#1, but he/she will complete them independently. Both groups of children will receive a lesson on problem soiving with math word problems.

There are no risks or discomforts for my child in this research. Several benefits may result from my child's participation in this project. If my child is in group \#1, he/she will have the opportunity to work with another student to practice problem solving skills, teamwork, and skills for completing math word problems. If my child is in group $\# 2$, he/she will have the opportunity to learn about problem solving and gain practice in completing math word problems. The researcher will benefit by learning more about cooperative learning in elementary school children. 
All information in this study will be confidential. My name and my child's name will not be used. All records will be given numbers (for groups) and letters (for gender).

The decision whether or not to take part in this study is up to me and my child. My child does not have to participate. If I decide to allow my child to participate in the study, he/she may quit at any time. Whatever I decide will in no way effect my child's grades in school. If I wish for my child to quit I simply inform Neva Daniels at (401) 792-2758 of my decision.

If I am not satisfied with the way this study is performed, I may discuss my complaints with Neva Daniels, anonymously, if I choose. In addition, I may contact the office of the Vice Provost for Research, 70 Lower College Road, University of Rhode Island, Kingston, Rhode Island, telephone: (401) 792-2635.

I have read the Consent Form. My questions have been answered. My signature on this form means that I understand the information and I agree to allow my child to participate in this study.

Signature of Parent(s) or Guardian

Typed/printed Name

Date
Signature of Researcher

Typed/printed Name

Date 
Appendix B

Child Assent Form 


\section{Appendix B \\ Child Assent Form}

The University of Rhode Island

Department of Human Development and Family Studies

Transition Center

Lower College Road

Kingston, R.I. 02881

The Influence of Cooperative Learning

on Problem Solving and Self-Esteem

in Fourth Grade Elementary School Children

\section{CHILD ASSENT FORM FOR RESEARCH}

I have been asked by Neva Daniels, a graduate student at the University of Rhode Island, to participate in a project. I will be given information and directions by Neva Daniels. I can ask Neva Daniels any questions that I have about the project at any time.

This project will look at how fourth grade students solve math word problems.

During the project, I will be placed in one of two groups. If I am in group \#1, I will work on math word problems with another student and complete a math lesson with Neva Daniels. If I am in group \#2, I will work on math word problems by myself and complete a math lesson with Neva Daniels. At two different times, I will complete a series of questions that focus on how I feel about myself. At two different times I will also complete math word problems. The questions on how I feel about myself and the math word problems will be given to my class as a whole on the two different times.

This project will be safe for me. However, if I feel unhappy and want to quit at any time, I can tell my teacher and/or Neva Daniels. I will not be punished in any way if I decide to quit. My school grades will not be affected by my decision to quit.

I understand that this project will help me practice math word problems. This project will help Neva Daniels to learn more about how fourth grade students solve math word problems. 
My name will not be used in this project. A number, instead of my name, will be used to make sure my answers are kept private. All of my answers will be kept in sealed envelopes. The teacher or others will not see my answers. This project will not effect my grades in school. My teacher and classmates will not be told about how well I do on the math word problems. They also will not be told about my feelings about myself.

I have read and I understand this form. My questions have been answered. My signature on this form means that I understand the information and $\mathrm{I}$ agree to participate in this study.

Signature of the child

Typed/printed Name

Date
Signature of Researcher

Typed/printed Name

Date 


\section{Appendix C \\ Piers-Harris Self-Concept Scale \\ (Pre- and Post-test)}




\title{
"THE WAY I FEEL ABOUT MYSELF"
}

\author{
The Plers-Harrls Children's Self-Concept Scale \\ Ellen V. Piers, Ph.D. and Dale B. Harris, Ph.O.
}

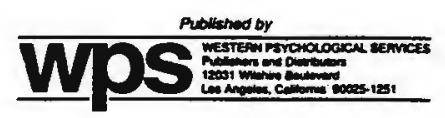

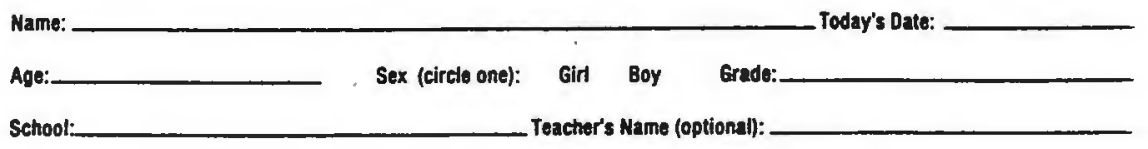

Directions: Here is a set of statements that tell how some people feel about themselves. Read each statement and decide whether or not it describes the way you feel about yourself. If it is true or mostly true for you, circle the word "yes" next to the statement. If it is false or mostly false for you, circle the word "no." Answer every question, even if some are hard to decide. Do not circle both "yes" and "no" for the same statement.

Remember that there are no right or wrong answers. Only you can tell us how you feel about yourself, so we hope you will mark the way you really feel inside.

TOTAL sCoRE: Raw Score Percontile___ Stanine cLustens: it

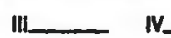

V. n 
Copyright 1969 by Ellen V. Piers and Dala B. Harric. Reprinted by Neva Daniels for display purposes by perriesion of the publisher, Western

Psychological Services, 12031 Wilshire Boulevard, Los Angeles, Callformia 90023.

Vot to be reprinted in whole or in part for any additional purpose without the

expressed, written permission of the publisher. All rights reserved.

\begin{tabular}{|c|c|}
\hline 1. My classmates make fun of me ..................... yes & no \\
\hline 2 I am a happy person ........................... yes & no \\
\hline 3. It is hard for me to make friends ................... yes & no \\
\hline 4. I am often sad ..................................yes & no \\
\hline 5. I am smart ......................................... yes & no \\
\hline 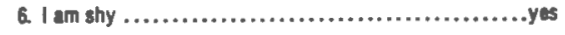 & no \\
\hline 7. I get nervous when the teacher calls on me ............ yes & no \\
\hline 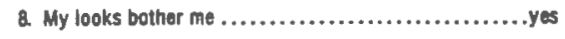 & no \\
\hline 9. When I grow up. I will be an important person ......... yes & no \\
\hline 10. I get worried when we have tests in school ........... yes & no \\
\hline 11. I am unpopular .................................yes & no \\
\hline 12 I am well behaved in school ..................... yes & no \\
\hline 13. th is usually my fault when something goes wrong ..... yes & no \\
\hline 14. I cause trouble to my family...................... yes & no \\
\hline 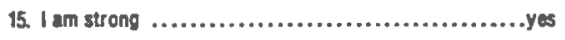 & no \\
\hline 16. I have good idess .................................yes & no \\
\hline 17. I am en important mamber of my family ............. yes & no \\
\hline 12. I usually want my own way ....................... yes & no \\
\hline 19. I am good at making things with my hands ............ yes & no \\
\hline 20. I oive up assily. & no \\
\hline
\end{tabular}

21. I am good in my school work ...................yes no

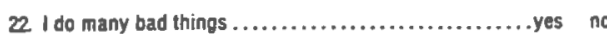

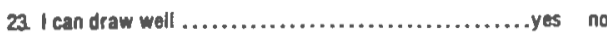

24. I an good in music ......................... yes no

25. I behave badly at home...$\ldots \ldots \ldots \ldots \ldots \ldots \ldots \ldots$. yes no

26. I am slow in finishing my school work................ yes no

27. I an en important member of my class ............. yes no

28. I am nervous $\ldots \ldots \ldots \ldots \ldots \ldots \ldots \ldots \ldots \ldots \ldots$. yes no

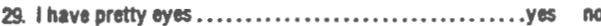

30. I can give a good report in front of the class .......... yes no

31. In school I am a dreamer ....................... yes no

2 I pick on my brother(s) and sister(s) ...............yes no

33. My triends like my ldeas ....................... yes no

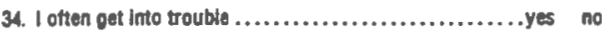

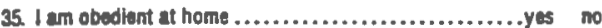

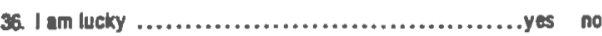

37. I worry a tot ...............................yes no

38. My parents expect too much of me................. yes no

39. Ilike being the way I am .......................... yes no

40. I feet left out of things $\ldots \ldots \ldots \ldots \ldots \ldots \ldots \ldots \ldots$...... nes no 
Copyright $\$ 1969$ by Ellen V. Piers and Dale B. Harric. Reprinted by Nava

Daniels for display purposes by permiccion of the publisher, Western

Psychological Services, 12031 Wilshire boulevard, Los Angeles, Callfornia 90025

Not to be reprinted in whole or in part for any additional purpose without the

expressed, written permisision of the publisher. All rights reserved.

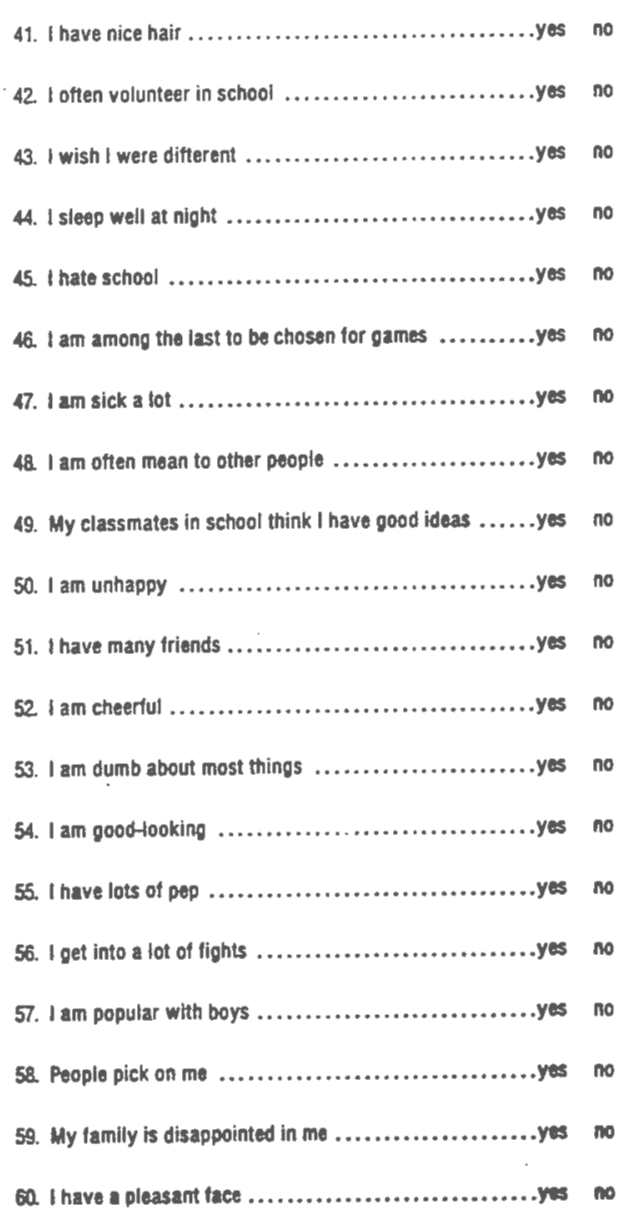

61. When I try to make something. everything soems to

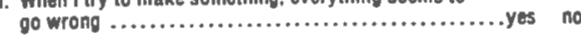

$62 !$ am picked on at home ...........................yes no

6. I am a leader in games and sports ................yes no

64. I am clumsy ...............................yes no

65. In games and sports, I watch instead of pley .......... yes no

66. I forget what I loam $\ldots \ldots \ldots \ldots \ldots \ldots \ldots \ldots \ldots \ldots$. . . nes no

67. I an easy to get along whth ..................... yes no

68. I lose my temper easily ........................yes no

I am popular with girls .........................yes no

$70 \mathrm{l}$ am a good reader ........................... yes no

71. I would rather work alone than with a group .......... yes no

72 I like my brother (sister) $\ldots \ldots \ldots \ldots \ldots \ldots \ldots \ldots \ldots$. yes no

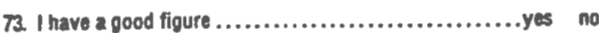

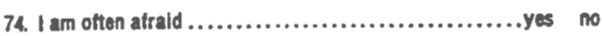

75. I am always dropping or breaking things ............ yes no

76. I can be trusted $\ldots \ldots \ldots \ldots \ldots \ldots \ldots \ldots \ldots \ldots \ldots$. yes no

7. I an different from other people ................... yes no

76. I think bad thoughts $\ldots . \ldots \ldots \ldots \ldots \ldots \ldots \ldots \ldots \ldots$. yes no

7 I cry easily ................................. nes no

c. I an a god person ........................... yes no 


\section{Appendix D \\ Piers-Harris Self-Concept Scale \\ Profile Form}




\section{The Piers-Harris Chlldren's Self-Concept Scale}

Ellen V. Piers, Ph.D. and Dale B. Harris, Ph.D.

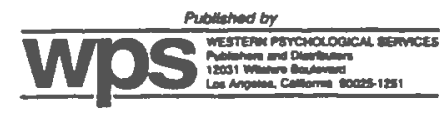

Today's Date:

School: Teacher's Name (optional):

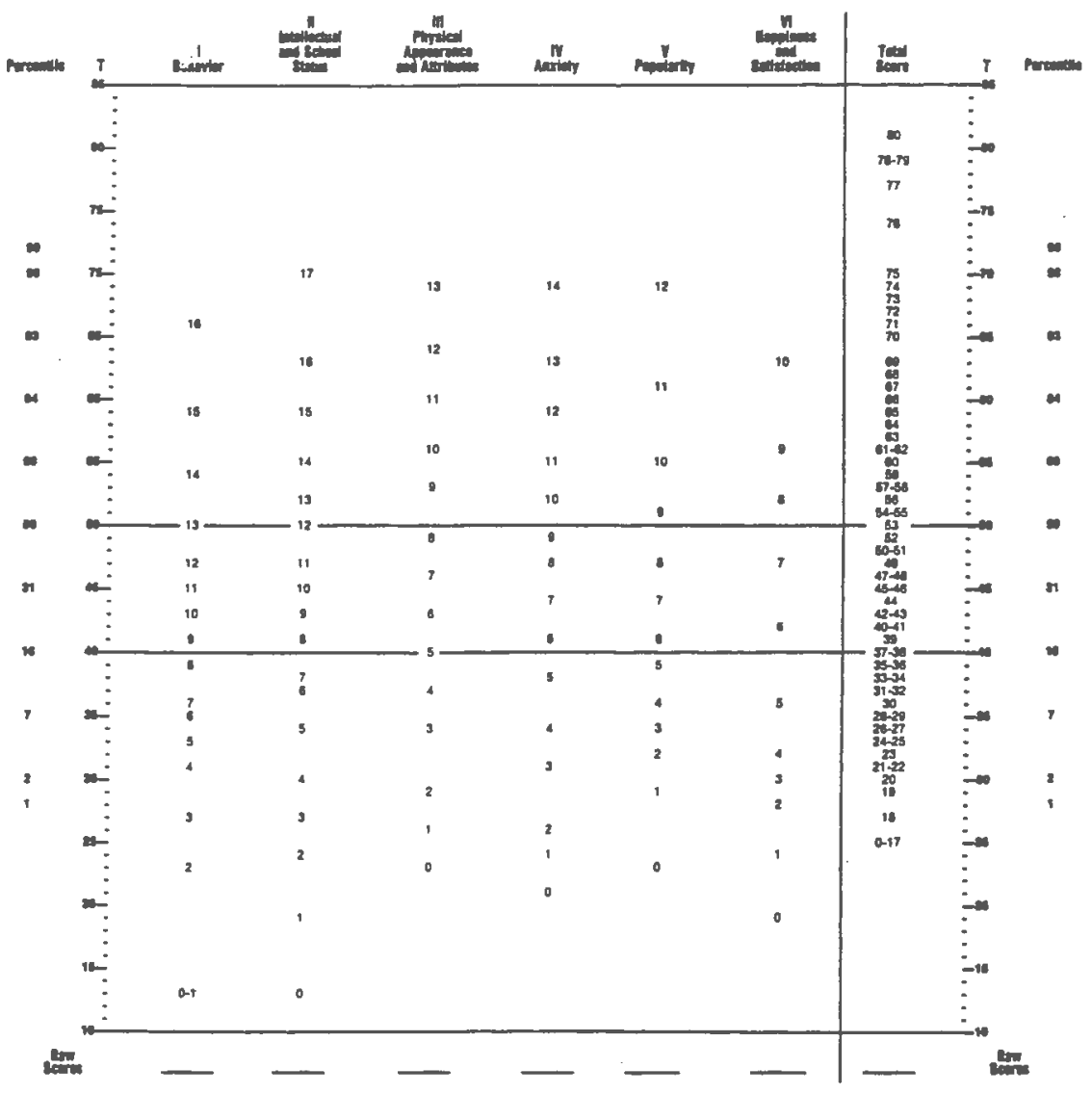

CODVTiOM • 1963 bv WESTEPH PSYCHOL OGICAL SERMCES

Copyright 1969 by Ellen V. Piers and Dale B. Harris. Reprinted by Neva

Danicls for display purposes by permission of the publisher, Western

Psychological Services, 12031 Wilshire Boulesard, Los Angeles, Callfornia 90025.

Not to be reprinted in whole or in part for any additional purpose without the

expressed, iwritten permission of the publisher. All rights reserved. 


\section{Appendix E \\ Piers-Harris \\ Copyright Information}




\section{$140 \begin{aligned} & \text { WESTERN PSYCHOLOCICAL SERVICES } \\ & \text { Putlisnars anC Distitituicrs SinCe } 1948\end{aligned}$}

IO FAX $101 / 874-4020$

1 page total:suiw

March 29, 1996

\section{Neva Daniels}

Deparment of Hunan Development and Family Studies

Lniversity of Rhode Island

Kingstm, RI 02881

\section{Dear Ms. Daniels:}

Thark yuu for your fax and phone cails today, reguesting permission to reproduce WPS material for inclusion in an appertix of your thesis.

Uute to margin requirezients at the Liniversity of Khode Lsland, Western Psychoiogical Services dithorizes yu to photoreduce in original Test Eooklet (product number W-180A) for the Piers-Harris Chiluren's Salf-Coresp? Scate (PHCSCS), for the above-described purpose only, provided each reprint bears the following required notice is its entirety:

Copyraght 1969 by Ellen V. Piass and Dale B. Harris. Reprinted by Neva Danicls for display purposes by permikuion of the publisher, Western

Psychological Services, 12031 Vilshire Boulevard, Los Angeles, Callfornla 90025.

Not to be reprinted in whole or in part for any additional purpose without the

expressed, written permission of the publisher. All inghts reserved.

Please note that this autholzation does not extend to reproduction by microfilm. Due to the public availability of mictofined copies, WPS is not to authorize reproduction of its tests in this manner. While we regret any incomienience nur position, may cauce, we trust you understand the ethical considerations involved.

We eppreciate you interest in the PHCSCS as well as your consideration for its copyright. If you have any follow-up questions, please foel free to contact me again.

SDW:se

Sincerely yours

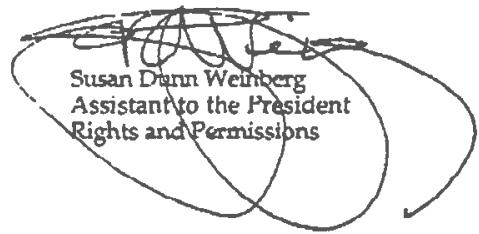

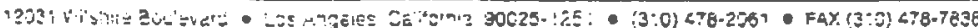


Appendix $\mathrm{F}$

Pre- and Post- Math Test 


\section{Appendix F}

Pre-test and Post-test word problems samples

Taken from The Mathematics Experience Grade Four

(Houghton Mifflin 1992).

Directions: Please use your problem solving skills to solve each of the problems below. Please show all work on a separate sheet of paper.

1. What two consecutive (next to each other) numbers have the sum of 67 ?

2. Mr. Yamamoto brought 7 videotapes for a total price of $\$ 93.27$. Some of tapes sold for $\$ 12.49$, while the rest were priced at $\$ 13.95$. How many of each price did he buy?

3. Jimmy has 3 pairs of socks- white, brown and blue. The light is out, and Jimmy cannot see the colors of the socks. What is the least number of socks he must pull out to be sure of having at least one matching pair ?

4. What two consecutive numbers have a product of 156 ?

5. Monica has 39 books on 3 shelves. She has 2 more books on the bottom shelf than on the middle shelf and 2 more books on the middle shelf than on the top shelf. How many books are on the top shelf ?

6. Tami is designing a large space station. Each floor has one less room than the floor below. There are 42 rooms on 4 floors. How many rooms are on the second floor ? 
7. Alex had 36 goldfish. He divided them equally into 4 aquariums. Then he gave one of the aquariums and fish to his cousin. How many fish did Alex have left ?

8. Bob and Brenda each had 8 books. Chris and Claudia each had 12 books. Donald had 5 books. If they put the books in a pile and shared them equally, how many books did each person receive ?

9. Esther and Camille each threw 24 snowballs at a fence post.

Esther hit the post 8 times. One half of Camille's snowballs hit the fence. How many more times did Camille hit the fence than Esther?

10. There are 56 houses in Lane's neighborhood. Each street has 7 houses on it. Only two houses on each street bought cookies from Lane. If he sold 2 boxes of cookies at each house, how many boxes of cookies did he sell ?

11. Jane, Jasmin, and Jessica played 18 games of horseshoes. Jane won one half the games. Jasmin won one third the games. How many games did Jessica win?

12. Sandy had a jar filled with marbles.

She asked everyone to discover the number of marbles.

Sandy gave these clues.

*It is more than 20 , and less than 40 .

* It can be divided evenly by 6 .

*It cannot be divided evenly by 5 or 8 .

13. Carlos gave these clues to find the number of players on his team.

*It is more than 4 , and less than 20 .

*It cannot be divided evenly by 2,5 or 7 .

* It can be divided evenly by 3 .

14. Tom bragged that no one would guess the exact number of fruit bars in his bag. He gave these clues.

*It is between 20 and 40 .

*It can be divided evenly by 6 and 4 .

*It cannot be divided evenly by 7 . Was Tom right ? 
15. Ursula gave these clues to guess the age of her uncle.

*If you add 10 it is still less than 50 .

*If you subtract 10 it is still more than 10 .

*It is the product of some number multiplied by itself.

*It cannot be divided evenly by 2 or 9 .

How old is Ursula's uncle?

16. Enjoli is making a chain out of paper strips. The first strip is green. The next two are red. The pattern is repeated.

What is the color of the eleventh strip of paper in the chain ?

17. Caitlin is saving money for a set of paints which cost $\$ 30$.

She saves $\$ 1$ the first week, $\$ 2$ the second week, $\$ 3$ the third week. If this pattern continues, after how many weeks will she have enough money to buy the paints ?

18. To solve a secret code, Barry crosses out every third letter in the alphabet. What is the fourth letter Barry will cross out ?

19. Christie went on a bicycle trip. She traveled $12 \mathrm{mi}$ east, then $6 \mathrm{mi}$ south, then $10 \mathrm{mi}$ west, then $6 \mathrm{mi}$ north. At the end of her trip, about how far was she from her starting point ?

20. Janice has an older brother who is 16 and a younger brother who is 7. Janice's age is a multiple of 7. How old is Janice ?

21. Craig rode his bike $2.2 \mathrm{mi}$ from home to the park, $1.9 \mathrm{mi}$ through the park, and $2.7 \mathrm{mi}$ back home from the park. About how far did he ride ?

22. Party hats cost $\$ 1.79$ each. Mary Ann wants to buy 15 hats. If she has a $\$ 20$ bill, will she have enough to buy 15 hats ?

23. Seth read the same number of pages each day for 20 days. He read 280 pages in all. How many pages did he read each day?

24. Kerry has 24 roses. Of these, $1 / 3$ are yellow, $1 / 3$ are red. The rest are white. How many white roses does Kerry have ? 
25. Donna had $\$ 16.32$. She spent $3 / 4$ of her money on a new board game. How much did she spend on the board game ?

26. Alicia's puppy weighed only 2 pounds when she got her, but she gained $1 / 4 \mathrm{lb}$ every day the first week. How much did Alicia puppy weigh after the first week ?

27. Will is saving money for a video game which costs $\$ 20$. He plans to save $\$ 2$ the first week, $\$ 4$ the second week, $\$ 6$ the third week. If he continues this pattern, in how many weeks will he have enough money to buy the game ?

28. The play presented by Show Kids began at 7:30P.M. The first act was over at 8:20P.M. How long was the first act ?

29. At 4:11 Mrs. Gillet put money in the parking meter. It was enough for 2 hours 20 minutes of parking. By what time should Mrs. Gillet return to her car ?

30. Tina painted eggs and put them in old egg cartons to dry. She put a half dozen painted eggs in each carton. If she painted 76 eggs, how many cartons did she need ? 
Appendix G

Daily Math Word Problems 


\section{Appendix G}

\section{Practice word problems samples \\ (daily word problems)}

\section{Taken from The Macmillan Mathematics Book Grade Four (1987).}

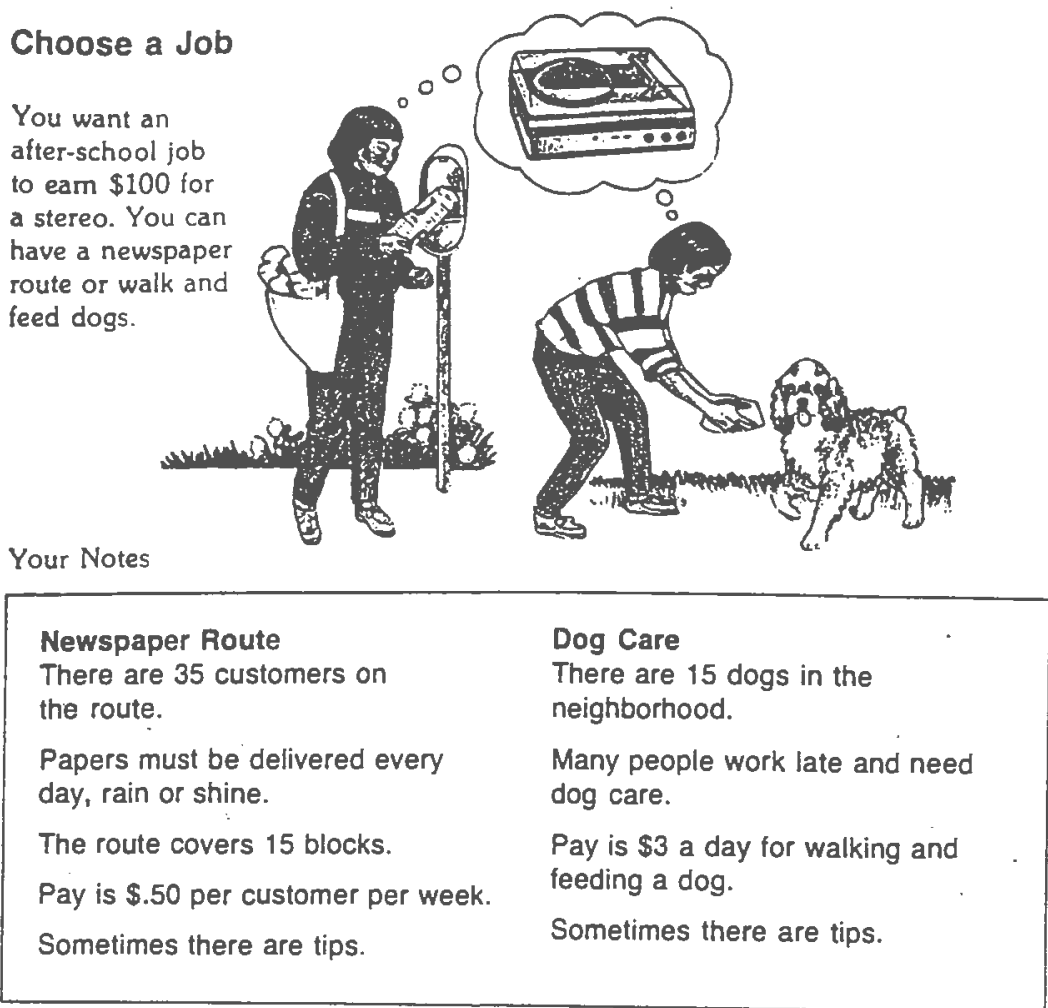

Work in small groups to find answers and make decisions.

Day 1 1. How much can you earn a week from the paper route?

Can you tell how much you may get in tips? \$17.50; no

2. How many days must you walk and feed one dog to eam $\$ 20$ ? 7 days

3. If you walk and feed two dogs each day. how long will it take to earn $\$ 20$ ?

Day $2 \quad$ Three dogs are the most you can manage. How much could you make in a days

5. What else should you think about? Answers will vary.

6. Which job will you take? Why? Answers will vary. 


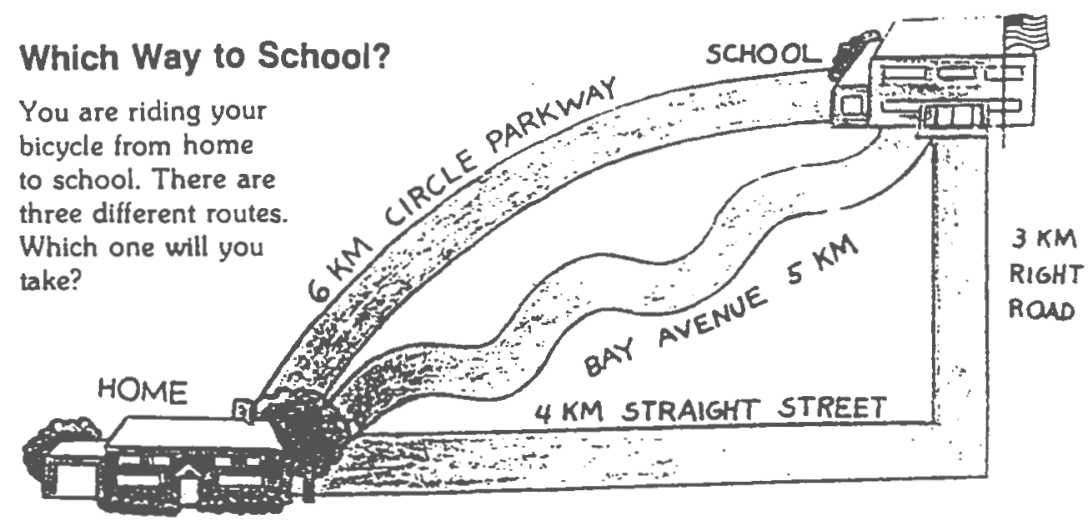

Your Notes

Bay Avenue Route

There are two big hills.

Straight Street

There is a lot of automobile traffic on Straight Street.

\section{Circle Parkway Route}

There is a train crossing that

sometimes delays traffic for 15 minutes.
Other

School opens at 8:00 A.M.

Must leave home after 6:30 A.M.

Riding speed averages 1 kilometer in 10 minutes on level ground.

\section{Work in small groups to find answers and make decisions.}

Day 3 . What is the distance if you choose the longest route? 7 kilometers

2. What is the difference in distance between the longest and shortest routes?

2. What is the difference in distance between the longest and shortest routes? 2 kilometers

- 3. How long would it take to ride 5 kilometers on level ground? $\mathbf{5 0}$ minutes

Day 4 4. How much longer would it take on the Bay Avenue route? can't tell

5. If you are delayed by a train, how long will the Circle Parkway route take?

6. What else should you thint about? Answers witt vary.

7. Which route will you take? Tell why. Answers will vary. 


\section{Go or No Go?}

You are going on a 5-day trip to Wyoming. Should you take your dog Fluffy or leave her at Pet Hotel?

Your Notes

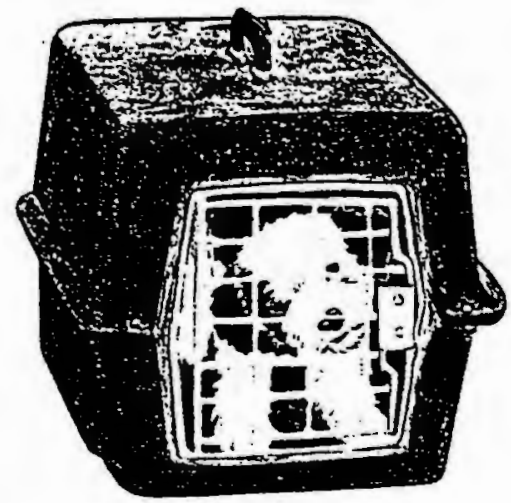

\section{Taking Fluffy}

Airlines charge $\$ 25$ round trip for a pet under 20 kilograms and $\$ 35$ round trip for a larger pet.

Fluffyiweighs 18 kilograms.

Food will cost \$2 a day.

Other:

Fluffy hates hot weather.

Tha

The average afternoon temperature

in Wyoming is about $40^{\circ} \mathrm{F}$.

\section{Leaving liuth}

Pet Hotel charge

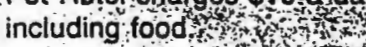

ar 3

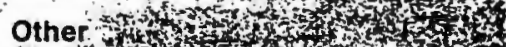

- Fluffi has never stayed at Pet

Hote - but Spótikes th there

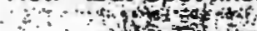

stint ats
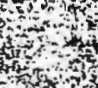

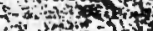

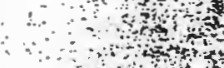

Work in small groups to answer questions and make decisions.

Day 5 . How much will the airline charge for Fluffy? $\$ 25$

2. How much will it cost to feed Fluffy if she comes along? $\$ 10$

3. How much will it cost to leave Fluffy at Pet Hotel? $\$ 50$

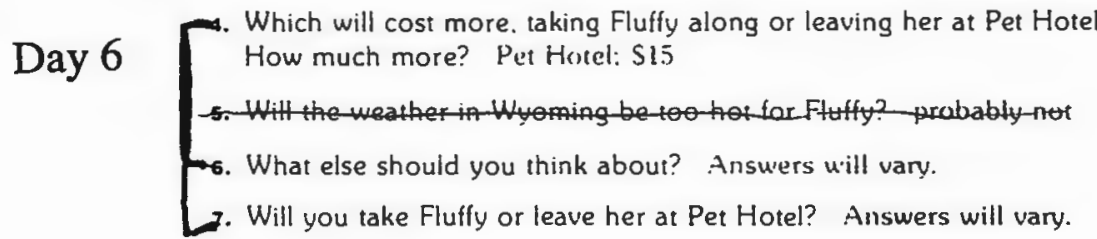


Mix or Homemade?

You promised to make

24 bran mulfins lor

the school bake sale

tomorrow. You can

use a packaged mix or

prepare the ingredients

yoursell. Which will

you do?

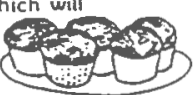

Your Notes
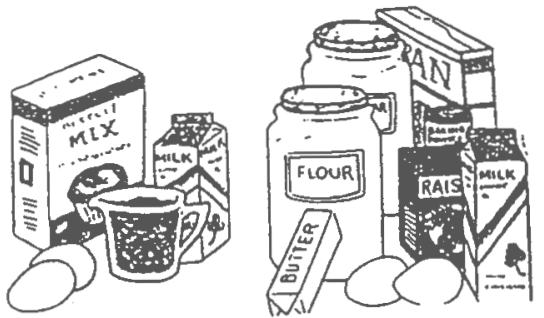

\section{Muffin Mix}

Each Mix package

needs two eggs

l cup milk

leup raisins

Using mix will take 15 minutes

Mix will make 12 miffins $\frac{\text { OWh Mix }}{\text { Need flour, sugar, butter }}$

milk, raisins.

Hounemade muffins taste

better. Will take 1/2to

make.

\section{Costs}

1 package of mix cests I.6C.

Work in small groups to find answers and make decisions.

Extra ingredients Cist 5.50

Ingredients for humeanade cis-

Day $7 \quad\left[\begin{array}{l}\text { s. ' ow much will' muffin mix tor } 24 \text { mulfins cost? } \\ \text { How much more must you spend" } \\ \text { 2. What is the difference in time to make the mutlins? } \\ \text { 3. "'hat is the total cost of } 24 \text { mulfins made with mix? }\end{array}\right.$

51.80 for 24 mutfiris.

Day $8\left[\begin{array}{l}1 \text { Which method is less expensive? What is the difference? } \\ \text { 2. Why might you use the mix? } \\ \text { 3. Will you use a packaged mix or prepare the ingredients yoursell? - }\end{array}\right.$ 


\section{Price a Product}

There is a crafts fair at school. You want to earn money by selling the bracelets you make. How much will you charge for each bracelet?

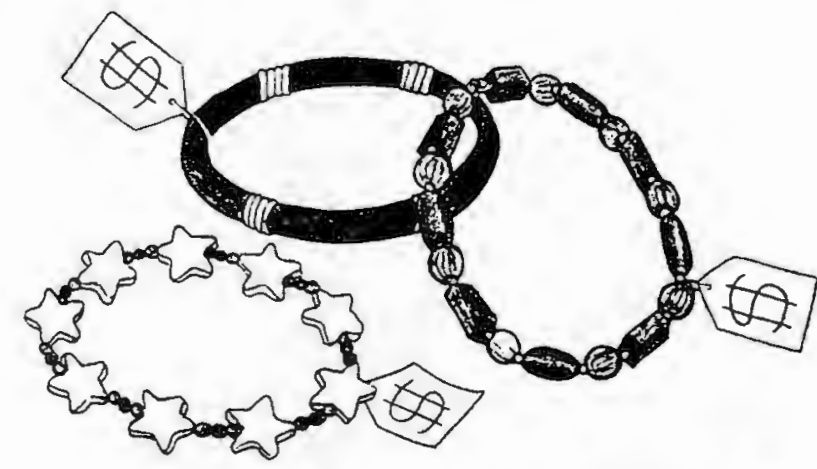

Your Notes

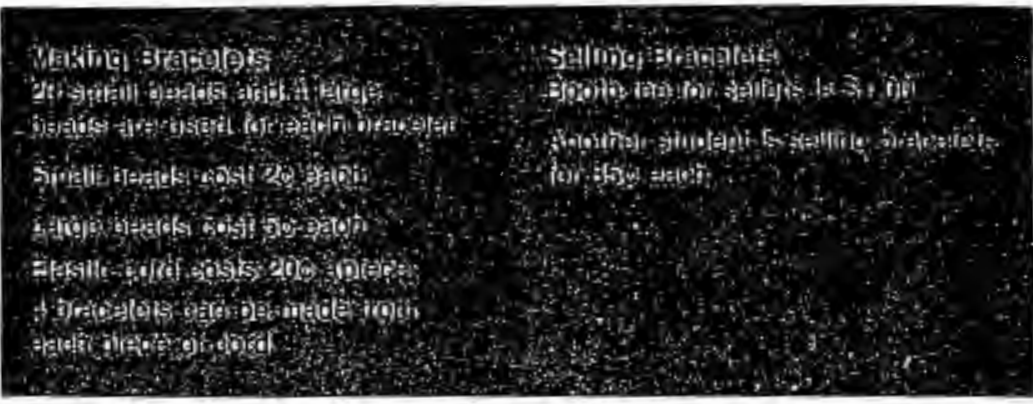

Work in small groups to find answers and make decisions.

Day $9\left[\begin{array}{l}\text {. How much do the beads for one bracelet cost? } 60 \mathrm{c} \\ \text { 2. How much does the cord for each bracelet cost? } 5 \mathrm{c} \\ \text {. What is the total cost of a bracelet? } 65 \mathrm{c}\end{array}\right.$

Day $10\left[\begin{array}{l}\text { 4. If you sell the bracelets at } \$ 1.00 \text { each. how much will you make on each? } 35 \mathrm{c} \\ \text { 5. If you sell } 7 \text { bracelets at } \$ 1.00 \text { each. how much will you make on the bracelers? } \\ \text { c. How much will you have left for yourself after paying the booth fee if you sell }\end{array}\right.$ 7 bracelets? $\$ 1.45$

7. Whatelse-shoutdyou think about? Answers will vary.

8. - How much will you harge-for-yeur braceters?- Answers will wary. 
Appendix $\mathrm{H}$

Behavior Coding Sheet 
Appendix $\mathrm{H}$

Cooperative Activity Behavior Coding Sheet

\begin{tabular}{l|l|l|l|l} 
Children & $\begin{array}{l}\text { Suggestions } \\
\text { Statements }\end{array}$ & Questions & Unrelated & $\begin{array}{l}\text { Representing } \\
\text { Drawing/writing }\end{array}$ \\
\hline A. & & & & \\
\hline B. & & & & \\
& & & & \\
& & & & \\
& & & & \\
& & & & \\
\hline
\end{tabular}

60 


\section{Bibliography}

Adams, G. \& Schvaneveldt, J. (1991). Understanding_research methods (2nd Ed.). New York, NY: Longman.

Adler, A. (1970). The practice and theory of individual psychology.

New York, NY: Harcourt.

Bean, R. (1992). Individuality, self-expression and other keys to creativity. Santa Cruz, CA: ETR Associates.

Coopersmith, S. (1967). The antecedents of self esteem. San

Francisco, CA: W.H. Freeman \& Company.

Corsini, R. (1984). Encyclopedia of psychology (vol. 3). New York, NY:

John Wiley \& Sons.

Damon, W. (1984). Peer education: The untapped potential. Journal of Applied Developmental Psychology, 5, 331-343.

Forman, E. A., \& Cazden, C. (1983). Exploring Vygotskian perspectives in education: The cognitive value of peer interaction. In J.V.

Wertsch (Ed.), Culture, communication, and cognition: Vygotskian

perspectives. New York, NY : Cambridge University Press.

Glasser, W. (1975). Reality therapy: A new approach to psychiatry.

New York, NY: Harper \& Row.

Horney, K. (1966). Our inner conflicts. New York, NY: W. W. Norton \& Company.

Haubner, M.A., Rathmell, E., \& Super, D. (1992). The mathematics experience grade four. Boston, MA: Houghton Mifflin Company. 
Huck, S., Cormier, W., \& Bounds, W. (1974). Reading statistics and research. New York, NY: Harper Collins Publishers.

Hudgins, B. (1960). Effects of group experience on individual

problem solving. Journal of Educational Psychology, 51(1), 37-42.

Keyser, D. J., \& Sweetland, R. C. (1984). Test critiques: Volume I.

Kansas City, MO: Test Corporation of America.

Lester, F.K., \& Garofalo, J. (1982). Mathematical problem solving:

Issues in research. Philadelphia, PA: Franklin Institute.

Maslow, A. (1970). Motivation and personality (2nd ed.). New York,

NY: Harper \& Row.

Mitchell, J.V. (1985). The ninth mental measurements yearbook.

(vol.2). Lincoln, NE: University of Nebraska-Lincoln.

Mussen, P.H. (1983). Handbook of child psychology (vol. 4). New

York, NY: John Wiley \& Sons.

Piers, V. (1977). Children's self-esteem, level of esteem certainty and responsibility for success and failure. The Journal of Genetic Psychology, 130, 295-304.

Polya, G. (1973). How to solve it (39th ed.). Princeton, NJ: Princeton University Press.

Sears, P., \& Sherman, V. (1966). In pursuit of self-esteem: Case studies of eight elementary school children. Belmont,

CA: Wadsworth Publishing Company.

Sharan, S. (1980). Cooperative learning in small groups: Recent methods and effects on achievement, attitudes, and ethnic relations, Review of Educational Research, $\underline{50}(2), 241-271$. 
Silver, E.A. (1983). Teaching and learning mathematical problemsolving: Multiple research perspectives. Hillsdale, NJ : Erlbaum.

Slavin, R. (1980). Cooperative learning. Review of Educational Research, $\underline{50}(2), 315-342$.

Sullivan, H. (1953). The interpersonal theory of psychiatry. New York, NY: Norton.

Thoburn, T. (1987). Macmillan mathematics book grade four. New York, NY: Macmillan Publishing Company.

Tudge, J. (1992). Processes and consequences of peer collaboration:

A Vygotskian analysis. Child Development, $\underline{63}$, 1364-1379.

Tudge, J., \& Caruso, D. (1988). Cooperative problem solving in the classroom: Enhancing young children's cognitive development. Young Children, 44, November, 46-52. 